\title{
REVERZIBILNE HIDROELEKTRANE SMANJUJU TROŠKOVE PROIZVODNJE I OBEZBEĐUJU ČISTU ENERGIJU VETRA I SUNCA
}

\author{
Aleksandar Gajic ${ }^{*}$, Stanislav Pejovic ${ }^{2}$, Bryan Karney ${ }^{3}$ \\ 1 Univerzitet u Beogradu, Mašinski fakultet, \\ 2Prof. Emeritus, 300 Webb Drive \#1411, Mississauga, Ontario, Canada L5B 3W3, \\ 3 University of Toronto, Civil Engineering Department, Canada, M5S 1A4, \\ Review paper \\ DOI: 10.5937/termoteh
}

\begin{abstract}
Pretvaranje električne energije $u$ druge oblike energije $i$ njeno skladištenje $u$ periodima smanjene potrošnje ili raspoložive povećane proizvodnje, kao $i$ proizvodnja električne energije u periodima povećane potražnje ili smanjene proizvodnje, jesu od krucijalnog značaja za stabilnost $i$ efikasnost elektroenergetskog sistema. Ovaj zahtev je posebno izražen danas zbog ekspanzije uključivanja vetrogeneratora i solarnih elektrana u elektroenergetski sistem. Ovi obnovljivi izvori su inherentno promenljivi, kako u dnevnom periodu, tako i u periodima od nekoliko dana, nedelja ili meseci. Stoga je neophodno obezbediti zamenske kapacitete i postrojenja za akumulaciju energije. Razlicite tehnologija se mogu koristiti za konverziju i akumulaciju električne energije, ali jedina u potpunosti razvijena raspoloživa tehnologija velikog kapaciteta je bazirana na reverzibilnim hidroelektranama. U okviru ovog rada se razmatra potencijal reverzibilnih hidroelektrana za efikasno i ekonomski prihvatljivo skladištenje električne energije proizvedene $u$ vetroelektranama, u solarnim elektranama, protočnim hidroelektranama i iz drugih obnovljivih izvora, kao iz konvencionalnih termoelektrana, uključujući $i$ nuklearne elektrane. Gasnoturbinska postrojenja i gasni motori zagađuju okolinu i utiču na klimatske promene. Za realizaciju reverzibilnih hidroelektrana se koriste reke $i$ jezera. Međutim, pored ovih rešenja sa korišćenjem prirodnih pogodnosti, pojavila su se nova rešenja, kao što je korišćenje mora kao donjeg rezervoara (Japan), ili predlozi da gornji rezervoar bude površinski, a donji podzemni, korišćenjem prirodnih kaviteta ispod tla. Analize pokazuju da je opravdano investirati u reverzibilne hidroelektrane. Primeri iz svetske prakse pokazuju da se rešenje sa podzemnom mašinskom halom može otplatiti za sedam do deset godina ili čak za pet godina pri ostvarivanju mogućeg maksimalnog prihoda. Reverzibilne hidroelektrane sa površinskim akumulacijama se mogu otplatiti čak za četiri do šest godina.
\end{abstract}

Ključne reči: Reverzibilna hidroelektrana, obnovljiva energija, akumulacija.

\section{UVOD - ZAŠTO REVERZIBILNE HIDROELEKTANE}

Akumulacione i reverzibilne hidroelektrane omogućavaju optimizaciju električne mreže, pomažu u sprečavanju raspada sistema i limitiraju varijaciju cene energije. Drugim rečima ublažavaju posledice promena cena energije na tržištu, varijaciju proizvodnje vetroelektrana i solarnih elektrana kao i potrošnje, tehničkih problema proizvodnje, odnosno povećavaju profit i pouzdanost elektroenergetskog sistema. 
Reverzibilne ili pumpnoakumulacione hidroelektrane su od izuzetnog zančaja kao najpouzdaniji i najprilagodljiviji vid akumulacije čiste energije, dobijene iz onovljivih izvora: vetro i solarnih elektrana i pribranskih hidroelektrana. Ove hidroelektrane mogu zameniti do $50 \%$ proizvodnje nuklearnih i termoelektana na ugalj. Pumpno akumulacione hidroelektrane su najbolja lako upravljiva i najefikasnijia postrojenja ove namene, bez čijeg prisustva bi bila otežana, skoro nemoguća primena nuklearnih i termoelektrana.

Vetro i solarna energija su istovremeno čisti i obnovljivi izvori energije; oni su najbrže rastući izvori električne energije i biće značajan učesnik u bliskoj budućnosti. Ipak, do danas varijabilnost vetra i nesposobnost generatora za uravnoteženje proizvodnje je ostao primarni problem. Da bi vetro i solarne elektrane dostigle svoj puni potencijal treba naći sposoban način skladištenja električne energije.

$\mathrm{U}$ ovom trenutku je nemoguće direktno akumulirati električnu energiju i zato se mora usaglasiti proizvodnja i potrošnja energije u elektroenergetskom sistemu. Potrošnja energije iz električne mreže mora uvek da bude jednaka energiji isporučenoj od strane električnih generatora. Ako to nije slučaj, frekvencija i napon će varirati sa teškim poremećajima u snabdevanju / opterećenja bilansa i sistem se može raspasti. Sistem za prenos električne povezuje sisteme distribucije i obezbeđuje alternativnu proizvodnju i paralelne tokove u slučaju teškoća (nastalih usled vremenskih uslova i problema opreme). Generatori pokrivaju zahteve, ali prenosni sistem ima ključnu ulogu u povezivanju distribuiranih izvora i potrošača. Ako proizvodnja, potražnja i prenos nisu u ravnoteži, oprema će se isključiti u pokušaju da zaštiti sistem. Ako je neravnoteža teška, doći će do raspada.

Pumpnoakumulacione hidroelektrane imaju odličnu upravljivost u radu. Hidroelektrana može da se pokrene do pune snage za nekoliko minuta. Operatori elektroenergetskog sistema obično drže pumpnoakumulacione hidroelektrane u takvom režimu, tako da su pumpe-turbine spremne da pokriju sve pikove potrošnje. Ipak, moguće je da se i dalje poboljša manevarnost sa rotiranjem pumpe-turbine u vazduhu, bilo u pumpnom ili u turbinskom smeru obrtanja. Dostizanje pune snage iz ovih rezervnih režima može da se ostvari za manje od 10 sekundi, bilo u pumpnom bilo u turbinskom režimu. Ovi režimi su najčešće istovremeno režimi sinhronih kompenzatora, za poboljšanje faktora snage i smanjenje gubitaka prenosa u dalekovodima, koji mogu biti čak mnogo više od potrošnje za pogon.

Rad pumpno akumulacionih postrojenja je često potpuno automatizovan, i automatski reaguje na promenu frekvence. Kao rezultat svih ovih koristi, može se zaključiti da reverzibilne hidroelektrane doprinose ukupnom kvalitetu električne mreže i poboljšanu pouzdanosti sistema.

Pumpne elektrane omogućavaju smanjivanje troškova i ekologije i ekonomije. Ključna prednost je dostizanje efikasnog, pouzdanog i stabilnog sistema napajanja i ostvarivanje uslova za iskorištavanje prednosti koje nudi obnovljivi izvori energije. Tržište električne energije treba da podrži komplementarnu prirodu skladištenja i proizvodnje energije iz solarnih i vetroparkova. Osim toga, nuklearne i termoelektrane na ugalj kao visoko inercijska postrojenja ne mogu podržati iznenadne zahteve tržišta i ostvariti nepredviđena balansiranja. Mora se naglasiti da elektrane na prirodni gas doprinose očuvanju životne sredine i spečavanju klimatskih promena malo manje od uglja. Ovakve elektrane mogu uspešno pomoći u balansiranju proizvodnje vetroelektrana, ali povećavaju zagađenje životne sredine.

Pumpno akumulacione hidroelektrane mogu da akumuliraju energiju, i plasiraju je kada to mreža zahteva. Sasvim je uobičajeno takođe, da se konvencionalne hidroelektrane koriste samo u vreme kada je najveća potražnja za energijom. One su veoma dobre za ovu svrhu, jer se mogu brzo i startovati i zaustaviti, $i$ to sa malim troškovima. Da bi ova uloga bila pouzdana potrebna je dovoljna zapremina gornje akumulacije. Ova funkcija je od vitalnog značaja za nuklearne i termoelektrane na ugalj, koje se takođe u ovu svrhu mogu promeniti, samo je njihova promena režima veoma spora i sa ekstremno visokim troškovima i disipacijom i toplote i zagađenja.

Hidraulične mašine sa promenljivom brzinom obrtanja rade sve vreme sa najvećim stepenom korisnosti, uz visoko smanjenje vibracija, pa su operativni troškovi održavanja niži za čak $50 \%$. Ukupna efikasnost ciklusa je povećana; energija se skladišti noću, tokom male potrošnje, i vraća u elektro mrežu do $75 \%$ kao vršna energija. Samo, takva postrojenja zahtevaju velika ulaganja kapitala. Projektovanje, izgradnja i eksploatacija hidroelektrana zahtevaju rešavanje velikog broja detalja, dobro osmišljen i precizan projekat. Podprojekti moraju biti pažljivo koordinirani radi postizanja bezbednog, pouzdanog i ekonomičnog rada, i ostvarenja socijalnog, tehnološkog i ekološkog uspeha.

Vodonik kao gorivo ne može biti jeftin i ekonomičan za skladištenje električne energije. Efikasnost transformacije ciklusa (višak električne energije - vodonik - pik električne energije) je na nivou ispod 40\%, često čak i manje od 30\% (tzv. termodinamička uska grla). Vodonik je, s druge strane ozbiljan kandidat za zamenu benzina. Razni instituti istražuju nove tehnologije za proizvodnju vodonika kao čistog goriva za vozila. 


\section{ENERGIJE IZ TERMO, NUKLEARNIH, VETRO I SOLARNIH ELEKTRANA}

Vetar je čist i obnovljivi izvor energije; to je jedan od najbrže rastućih izvora električne energije i može biti značajan konkurent u bliskoj budućnosti. Do sada je varijabilnost vetra i nemogućnost regulacije količine proizvedene energije ostao primarni problem. Tu su periodi vremena kada vetroelektrane daju višak energije u odnosu na potrošnju. Takođe, postoje periodi slabog vetar ili kada ga uopšte nema, i kada nema proizvodnje energije [11]

Da bi vetar dostigao svoj puni potencijal, potreban je povoljan način za skladištenje energije. Nuklearne i termoelektrane na ugalj mogu menjati svoju snagu, ali uz izuzetno visoke troškove održavanja i rasipanje toplotne energije. Pored toga, zbog svoje velike inercije potrebno je značajno vreme da se prilagode na mrežu. Naftne i gasne elektrane, ako su van pogona, zahtevaju 15 do 20 minuta za dostizanje pune snage, a u slučaju da rade sinhronizovane na mreži još manje, ali i dalje ostaje problem emisije štetnih gasova. Pumpnoakumulacione hidroelektrane su kao balansni mehanizam za energiju vetra i sunca najbolji, i ekonomski i ekološki najprihvatljiije rešenje.

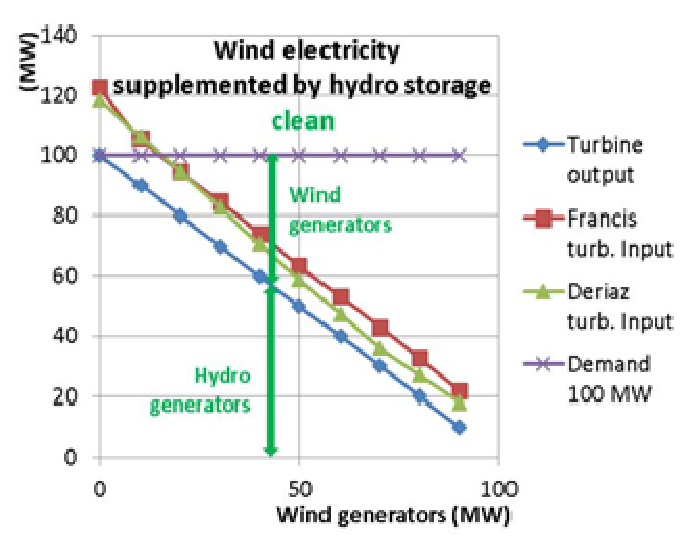

Slika 1: Vetro i hidroelektrane = čista energija

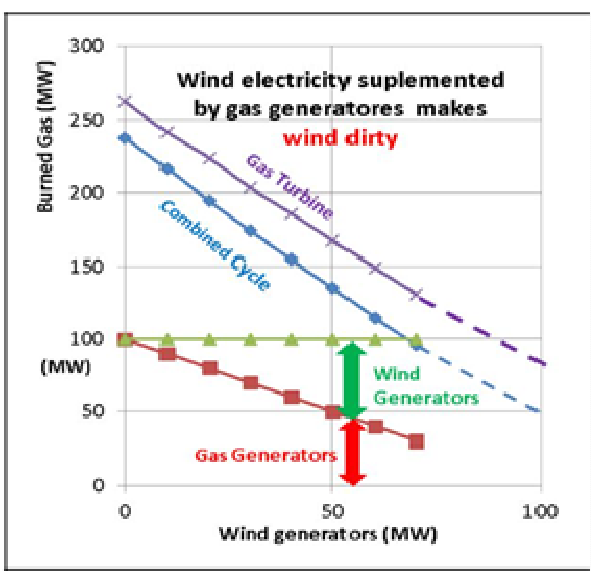

Slika 2: Vetro i termoelektrane na gas

Termoelektrane na prirodni gas sprečavaju zagađenje životne sredine i klimatske promene samo malo manje od uglja (Slika 2). Stoga je kombinacija energije vetra sa energijom iz hidroelektrana i pumpnoakumulacionih elektrana ključna strategija da bi se osigurao stabilan izvor čiste obnovljive energije (Slika 1).

Hidro i pumpno akumulacione elektrane imaju centralnu ulogu u funkcionisanju elektroenergetskog sistema. Oni su stabilizatori elektroenergetske mreže, pomažući da se osigura redovno snabdevanje električnom energijom i stabinost sistema. One mogu da uskoče u svakom trenutku kako bi proizvele dodatnu snagu u cilju da mreža ostvari sve svoje zadatke.

Zaključci zasnovani na analizi višegodišnjih skupljanja podataka o snagama vetra u Velikoj Britaniji u periodu 2008. do 2010. g. [28], ukazuju:

- Prosečna proizvodnja iz vetra je 24 - 27\%;

- Za četiri najviša pika potražnje energije, proizvodnja iz vetroelektrana je bila izuzetno mala, odnosno 4,7\%, 5,5\%, 2,6\% i 2,5\% snage;

- Raspoloživa snaga ispod $20 \%$ je tokom polovine vremena;

- Snaga od samo 2,5\% raspoloživa je tokom cele

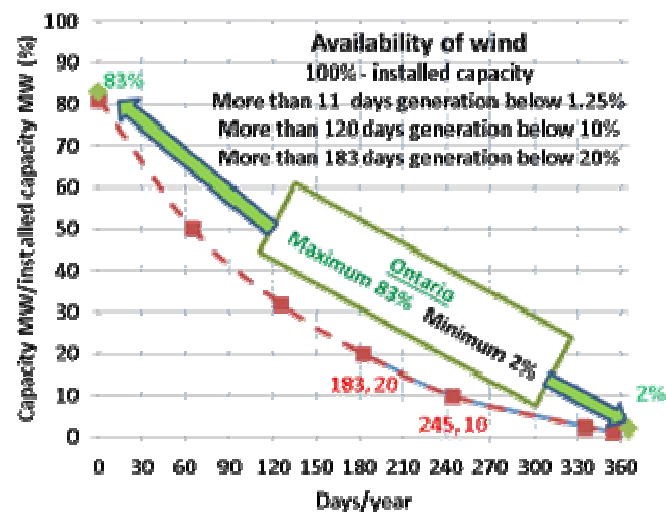

Slika 3. Raspoloživost vetra u V. Britaniji (2008. do 2010. i Kanadi ((IESO http://www.ieso.ca/) 
Analiza vetra u Ontariju, Kanada pokazuje skoro identične karakteristike, Slika. 3.

Postoji potreba za dugoročnim skladištenjem energije u dužim periodima bez vetra ili slabog vetra. Periodi u trajanju deset dana bez vetra nisu neuobičajeni ni u Nemačkoj. U oktobru i novembru 2011., ta država je doživela dugotrajnu blokadu za 44 dana uzastopno, izazivajući slom proizvodnje energije iz vetroelektrana. Tokom 27 dana u novembru, od 27,215 MW energije vetra instalirane u Nemačkoj u to vreme, vetrogeneratori su u stanju da samo obezbede sledeće [7]:

- $30 \%$ njihove potencijalne električne energije za samo 2 dana;

- $\quad 15 \%$ za 4 dana;

- $\quad 7$ - $8 \%$ za 5 dana;

- $\quad 4$ - $5 \%$ za 2 dana;

- $\quad 2-2,5 \%$ za 11 dana.

4.

Izuzetno nisko učešće vetra u proizvodnji električne energije u novembru 2011. godine je prikazano na Slici

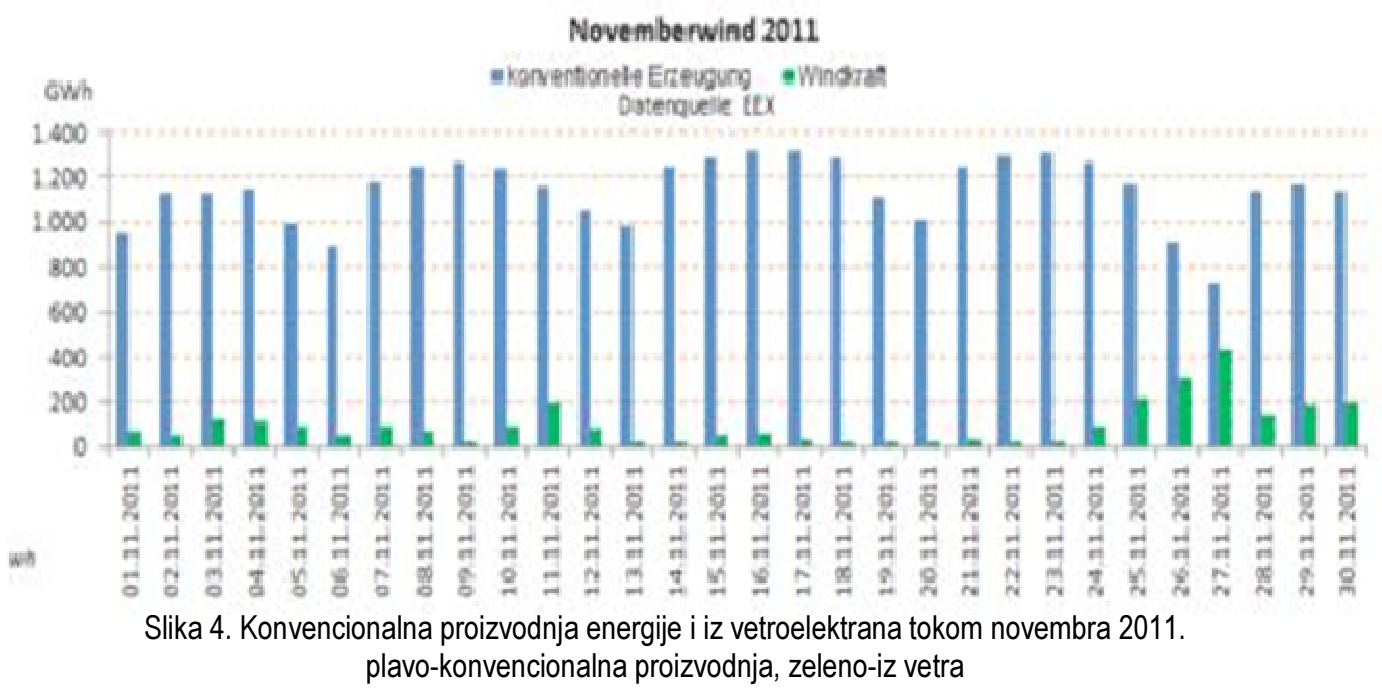

Zbog toga vetro i solarne elektrane ne bi trebalo da budu navedeni kao raspoloživi kapaciteti. Na primer, u 2010. godini Kanada je imala instaliran kapacitet 35,183 MW od kojih je 33,481 MW bilo dostupno. Do 2030. godine se očekuje da će instalirani kapacitet biti 40,900 MW a na raspolaganju samo 30,200 MW (Slika 5), [12]. Povećanje kapaciteta vetra i solarne energije treba pažljivo analizirati ili će se u suprotnom povećati nestabilnost, cena i zagađenje. Analize pokazuju da postoji jak ekonomski razlog za gradnju pumpnoakumulacionih postrojenja. Prema istraživanju ova postrojenja bi se isplatila za svega četiri do sedam godina [4]. Količina energije koja može da se čuva, podeljena sa količinom energije potrebne da za izgradnju je 21 puta bolja od najboljih litijumskih baterije i 110 puta bolji od olovnih akumulatora [21]. Drugi elektro i elektro-hemijski akumulatori su ili još uvek u razvoju ili su suviše skupi i ne mogu se takmičiti sa hidroakumulacijom [20].

\section{PUMPNOAKUMULACIONE HIDROELEKTRANE}

Konvencionalne hidroelektrane imaju ekspolataciona ograničenja u zavisnosti od varijacije padavina i nivoa vode u akumulaciji. Međutim, one mogu brzo da odgovore na zahteve mreže i njene nepravilnosti. Konvencionalne hidroelektrane mogu da akumuliraju energiju i proizvedu je kada je potražnja visoka. Sasvim je uobičajeno da se hidroelektrane koriste samo u vreme kada je najveća potražnja za energijom. One mogu da brzo startuju i brzo se zaustave po maloj ceni. Da bi to bilo pouzdano potreban je znatan gornji rezervoar, tzv. akumulacija. Konvencionalne hidroelektrane nemaju sposobnost da apsorbuju energije vetra, sunca i višak iz mreže kao što to 

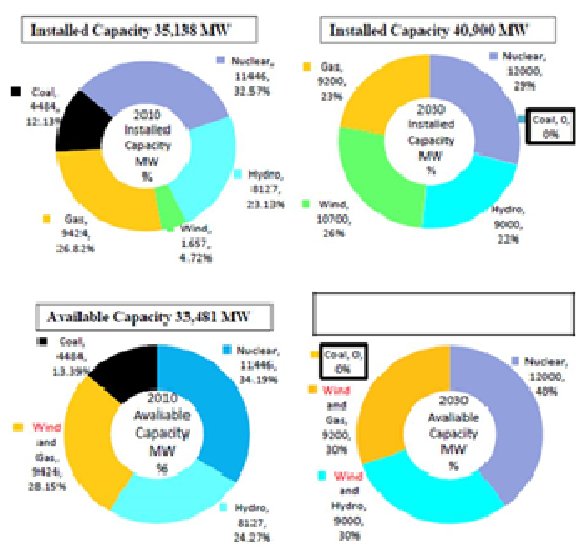

Slika 5. Planirani i instalirani kapaciteti u 2010 i 2030 mogu pumpnoakumulacione elektrane. Ova funkcija je od vitalnog značaja za nuklearne elektrane jer one mogu sporo da menjaju režim i reverzibilne hidroelektrane se mogu koristiti da apsorbuju njihovu proizvodnju noću. Troškovi održavanja termoelektrane na gas znatno rastu ako su primorane da smanje svoju proizvodnju noću. Cak i termoelektrane na naftu i na ugalj mogu da rade bliže svom optimumu, uz smanjenu emisiju štetnih gasova ako energetski sistem sadrži pumpnoakumulacione elektrane [25].

$\mathrm{Za}$ skladištenje energije kod pumpnoakumulacione hidrocentrale se koriste dva rezervoara vode na različitim visinama. Prilikom pumpnog režima voda se pumpa iz donjeg u gornji rezervoar. U suprotnom, generatorskom režimu, voda teče iz gornjeg u donji, obrće kolo turbine i proizvodi električnu energiju. Ovo je najčešći sistem za akumulaciju električne energije, koji zavisi od prirodnih uslova, obično koristeći reke ili jezera. Međutim, neki inovativni metodi su se pojavili poslednjih godina, kao što je korišćenje mora kao donji rezervoar (Japan) ili predlog da se koriste površinski rezervoar kao gornji rezervoar i podzemni rezervoar kao donji [4]. To je zrela tehnologija, široko rasprostranjena širom sveta, sa visokom izdržljivošću. Efikasnost starijih sistema se može povećati rekonstrukcijom vitalnih komponenti, posebno njihovh turbina. Nedostaci mogu biti ograničenja lokacije, duga prolazna vremena, pitanja zaštite životne sredine, kao i visoki početni troškovi. "Dinorvig" (Velika Britanija) sa 1800MW je najveći objekat te vrste u Evropi, sa izvanrednom sposobnošću brzog starta. RHE "Bajina Bašta" je prva akumulaciona elektrana sa jednostepenim pumpama-turbinama izgrađena u Evropi (Slika 6). Karakteristike različitih raspoloživih tehnologija za konverziju i skladištenje električne prikazani su u Tabeli 1, [4].

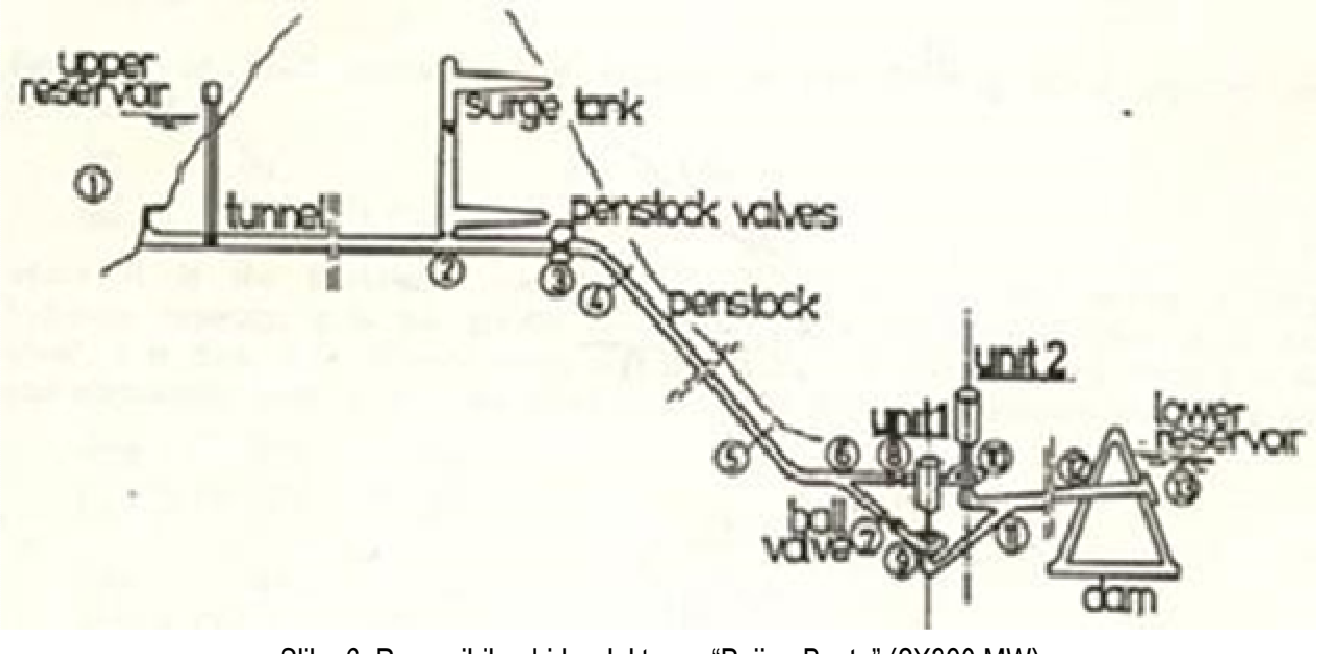

Slika 6: Reverzibilna hidroelektrana "Bajina Basta" (2X300 MW)

Osim toga, pumpnoakumulacione elektrane pružaju pomoćne usluge kao što su stanje pripravnosti mreže i rezervni režimi, start, kontrola frekvence, i fleksibilnost reaktivne snage. One se takođe mogu koristiti za ublažavanje reakcije tržišta. Proizvodnja i potrošnja mogu se optimizovati na sledeće načine: poboljšanjem efikasnosti, smanjenjem troškova, smanjenjem zagađenja, prevencijom raspada, porastom profita i poboljšanjem zaštite potrošačkih cena. 
A.Gajic et al.: Reverzibilne hidroelektrane smanjuju troškove proizvodnje i obezbeđuju čistu energiju vetra i sunca TERMOTEHNIKA, vol. 43, no. 1-4, 2017, pp. 39-47

\section{TEŠKOĆE I RASPAD SISTEMA}

Pumpnoakumulacione elektrane mogu obezbediti stabilnost mreže tokom nepredviđene havarije i spreče restrikcije. Troškovi SAD 2003. zbog nestanka struje su premašili 10 milijardi dolara i izazvali su 11 smrtnih slučajeva [2]. Sveobuhvatan pristup optimizaciji elektroenergetskog sistema omogućava realizaciju dva značajna cilja: prvo, za dobijanje rotirajuće rezerve, i istovremeno dostizanje optimalnog rada sistema. Ako mreža nije optimizovana privreda je ranjiva i svaki raspad može koštati milijarde dolara.

Tabela 1. Karakteristike energetske akumulacije, [4]

\begin{tabular}{|c|c|c|c|c|c|c|c|c|c|}
\hline & $\begin{array}{l}\text { Snaga } \\
(\mathrm{MW})\end{array}$ & $\begin{array}{l}\text { Rok } \\
\text { (h) }\end{array}$ & $\begin{array}{c}\text { Efikasnost } \\
(\%)\end{array}$ & $\begin{array}{l}\text { Trajanje } \\
\text { (god) }\end{array}$ & $\begin{array}{l}\text { Trajanje } \\
\text { (ciklus) }\end{array}$ & $\begin{array}{l}\text { Cena } \\
(\$ / k W)\end{array}$ & $\begin{array}{c}\text { Cena } \\
(\$ / k W h)\end{array}$ & $\begin{array}{l}\text { Tehn. } \\
\text { nivo } \\
(1-5)\end{array}$ & $\begin{array}{c}\text { Raspoloživ } \\
\text { ost } \\
(\%)\end{array}$ \\
\hline $\begin{array}{r}\text { Pumpno- } \\
\text { akumulcione } \\
\text { elektrane }\end{array}$ & $100-5000$ & $10-100$ & $70-87$ & $40-100$ & $12000-30000+$ & $600-2000$ & $5-100$ & 5 & $95+$ \\
\hline $\begin{array}{r}\text { Komprimvni } \\
\text { vazduh }\end{array}$ & $1-400$ & $2-100$ & $40-80$ & $20-100$ & $30000+$ & $400-800$ & $2-50$ & 5 & $65-96$ \\
\hline Led baterije & $0,001-50$ & h & $70-92$ & $\begin{array}{l}5-15 \\
(\sim 10)\end{array}$ & $500-1200$ & $300-600$ & $200-400$ & 5 & 99,997 \\
\hline Ni-Cd baterje & $0-46$ & $s-h$ & $60-70$ & $5-20$ & $1000-2500$ & $500-1500$ & $800-1500$ & 4 & $99+$ \\
\hline Li-ion baterije & $0,1-50$ & $0.1-5$ & $85-90$ & $5-20$ & $1000-10000$ & $1200-4000$ & $600-2500$ & 4 & $97+$ \\
\hline NaS baterije & $0,05-34$ & $5-8$ & $75-90$ & 15 & $2000-5000$ & $1000-3000$ & $300-500$ & 4 & do 99,98 \\
\hline $\begin{array}{r}\text { Metal-vazduh } \\
\text { baterije }\end{array}$ & $0,02-10$ & $3-4$ & $40-60$ & - & $100-300$ & $100-250$ & $10-60$ & 1 & $\mathrm{~N} / \mathrm{A}$ \\
\hline Gorive ćelije & $\begin{array}{c}0,000001- \\
50\end{array}$ & $\mathrm{~s}-24+$ & $20-70$ & $5-15$ & $1000-10000$ & $10000+$ & $6000-20000$ & 2 & 90 \\
\hline Thermo elektrane & $0,1-300$ & $1-24+$ & $30-60$ & $10-40$ & $2000-14600$ & $200-300$ & $3-60$ & $3-4$ & 90 \\
\hline
\end{tabular}

Vibracije su veoma važne, i moraju se analizirati i razmatrati „on-line“ sve vreme. Kada su vibracije blizu dozvoljenih limita rad agregata je dozvoljen samo pod pažljivim praćenjem i nadzorom; a ako je prekoračen limit, treba očekivati incident; agregat treba da se popravi kako bi sprečili havariju [11]. Proizvodni troškovi energije zavise uglavnom od intenziteta vibracija. Stopa porasta vibracija kao korelacija između izmerene vrednosti u realnom vremenu i referentne vrednosti, definiše preostalo vreme eksploatacije i veoma je važna karakteristika hidroagregata. Neki standardi, smernice i stručni radovi uzimaju u obzir vibracije i korelišu ih po stopi izloženosti u odnosu na podatke izmerene više stotina ili hiljada sati ranije. Amplitude i odgovarajuće frekvence vibracija i druge karakteristike mašina imaju jak uticaj na numeričke vrednosti stope ekspozicije. Statistička baza podataka sa podacima iz literature može da poboljša rad i spreči nepredviđene teškoće i havarije hidrogeneratora [11].

\section{FINANSIJSKA ANALIZA}

Analize pokazuju da postoji jak ekonomski razlog za gradnju pumpnoakumulacionih postrojenja pogotovo u nedostatku vršnih elektrana i drugih hidroakumulacija. Neizvesnost u vezi sa tržišnim pravilima su jedan od razloga zbog nedostatka investicija. Međutim, mnoge zemlje (uključujući Švajcarsku, Nemačku, Austriju i Kinu) su već investirali u reverzibilne hidroelektrane zbog ostvarivanja predvidivih koristi. Ključni faktori koji utiču na ekonomiju su smanjenje troškova, pravna ograničenja, i efikasnost. Analiza zasnovana na podacima tržišnih cena u SAD (Slika 7) pokazuje da bi pumpnoakumulaciona hidroelektrana sa visokim padom i podzemnom mašinskom halom se isplatila u 7 do 10 godina, sa prosečnim prihodima $(\$ 300.000 / \mathrm{MWgod})$ ili čak za 5 godina ako je prihod (\$ $600.000 / \mathrm{MWgod}$ ). Na povoljnim lokacijama povraćaj sredstava se može očekivati čak za četiri do šest godina [4].

Treba reći da neki energetski sistemi funkcionišu i bez pumpnoakumulacionih postrojenja. Ali, ekonomično skladištenje električne energije može da omogući efikasniji i pouzdaniji rad mreže. Za optimizaciju sistema takođe, može da se ostvari isporuka jeftinije energije i poveća profit. Korist može da bude smanjen broj maksimalnih opterećenja agregata (pikova i zagađenja), broj termoelektrana (nuklearnih, na uglja, naftu i gas), kao i opterećenje 


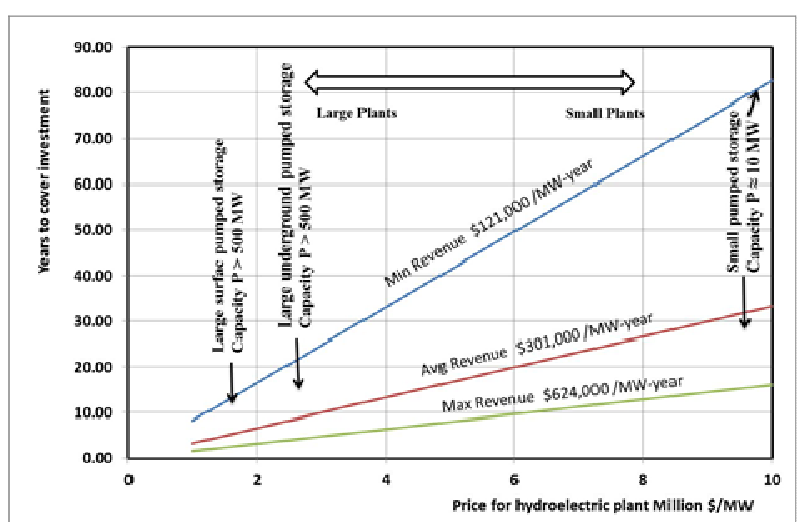

Slika 7: Broj godina rada za povraćaj investicija

prenosne i distributivne mreže. Uticaj zagađenja životne sredine kod pumpnoakumulacionih elektrana je manji od konvencionalnih hidroelektrana, jer je potražnja vode mnogo manja. Prosečni životni vek je veći do 100 godina; uticaj izgradnje i eksploatacije na životnu sredinu je veoma nizak [21]. Osim toga ove elektrane mogu da obezbede dodatne važne usluge kao što su kontrola frekvence, podrška stabilizaciji napona, i operativna rezerva, čime se povećava stabilnost i pouzdanost mreže, čak i smanjenje gubitaka prenosa i poboljšanje faktora snage.

Sve rotirajuće mašine imaju svoju inerciju. Za kontrolu porasta brzine obrtanja i pritisaka u dovodno-odvodnom sistemu inercija rotirajućih delova se veštački povećava. Optimizacija rotirajuće mase pumpi-turbina je često uslovljena zahtevima za regulaciju frekvence, što takođe može biti jedan od većih prihoda [4]. Analize pokazuju značajan doprinos povraćajem prihoda od $83 \%$, energije $12 \%$, i prihodom kapaciteta 3\% [4]. Tržišni uslovi imaju značajan uticaj na promenu ovih procenata.

\section{TEŠKOĆE I HAVARIJE HIDROELEKTRANA}

Hidroenergtsko znanje i iskustvo je dostiglo vrlo visok stepen zrelosti, ali je to znanje i iskustvo počelo da se gubi jer je bilo skriveno u nekoliko firmi, pa čak i ne baš visoki stručnjaci obično ne prenose tehnologiju na novo pristigle kadrove. Znanje mehanike fluida i primenjene matematike se mora primeniti u projektovanju i eksploatacij elektrana, ali iskustvo nas nažalost uči da veliki broj ima probleme u radu. Postoji vrlo malo objavljenih podataka o teškoćama, havarijama i nesrećama. Isti problemi i nesreće se onda ponovo javljaju i verovatno će se i u budućnosti ponoviti. Organizovan sistem obrazovanja, ne samo fakultetskog školovanja, je pravi način za moderni prenos iskustva. Kako je ljudski životni vek kratak, samo pravilno organizovan prenos znanja i iskustava može da podrži dalji napredak čovečanstva na osnovu visoke tehnologije.

Projektovanje elektrana, izbor i konstruisanje njihove opreme, i eksploatacija je kompleksan zadatak, koji zahteva visok stepen stručnosti i međusobne saradnje kolega srodnih profila. Finansijske analize, studije izvodljivosti i studije zaštite životne sredine obično zahtevaju široka planiranja, projektovanja i planove izgradnje. Dugi radni vek hidroelektrana i niska jedinična cena kao i niski troškovi proizvodnje mogu da kompezuju propuste, ali ne i da ih otklone.

Ako barijere, pravne i administrativne prirode, stoje na putu ekonomskih analiza, potencijal ove jeftine obnovljive energije će biti odložen. Mogući potencijal može potstaći ekonomski razvoj ako od strane vlade bude pružena odgovarajuća podrška kroz realizacije strategija energetike.

Istine radi, treba napomenuti da izgradnja hidroelektrana nije moguća bez nekog uticaja na životnu sredinu. Na primer, taj uticaj može biti u obliku ekoloških promena životinjskih i biljnih vrsta. Pored toga tu su promene toplotne energije registrovane u velikim jezerima, promene lokalne klime, povećanje minimalne i smanjenje maksimalne temperature.

\section{STANDARDI I PREPORUKE}

U vreme projektovanja RHE „Bajina Bašta“ (Slika 6), neki od preporuka i standarda nisu mogli da budu primenjeni, neki nisu ni postojali, a za određivanje vitalnih parametara sigurnosti i bezbednog rada oslanjalo se na iskustvo projektanta (Energoprojekt) i isporučioca opreme (Toshiba). Minimalni apsolutni pritisak u sifonu od 0,5bar nije odgovarao složenim uslovima strujanja na izlazu iz radnog kola, pa je primenjeno prethodno neobjavljeno iskustvo isporučioca. Ovo samo govori o čuvanju sopstvenih znanja i iskustva.

Preporuke za projektovanje hidroelektrane [1] još uvek nisu ažurirane! U međuvremenu su se desile mnoge neobjavljene i neke objavljene havarije [15].

Neke tehničke oblasti su izgubile dragoceno iskustvo i znanje koje su čuvale više od 100 godina. Čini se da je uzrok ovog gubitka loše koordiniran prenos praktičnog i teorijskog iskustva. Posledice su nestabilno tržište i 
investiciona klima, nesreće, neefikasnost rešavanja problema (istih problema) koji su se pojavljivali redovno u poslednjih nekoliko godina i pojavljivaće se i u budućnosti ako se ne preduzmu odgovarajuće mere. Organizovan multidisciplinarni prenos iskustava je glavni zadatak koji treba da se preduzmu nezavisne organizacije. Te odluke moraju da budu donesene u što skorije vreme. Postoji jasna potreba da se planiraju finansije i sprovede neke dugoročne inicijative [8].

\section{ZAKLJUČAK}

Pumpno akumulacione hidroelektrane nisu samo značajan ekološki čist izvor koji može nadoknadi potrebu zbog ograničenja proizvodnje vetroelektrana, već i balansirati ponudu i potražnju električne energije u distributivnim mrežama. One pomažu da sistem i tržište učine efikasnijim i pouzdanijim. Mogu da zamene do $50 \%$ nuklearnih i termoelektrana na ugalj. Lako se regulišu i upravljaju, stepen korisnosti ciklusa je $75-85 \%$. Njihovim angažovanjem u vreme povećanih zahteva za energijom (pikova potrošnje) umesto starijih postrojenja može se smanjiti emisija štetnih gasova, i akumulirati čistu energiju vetra, sunca, pribranskih hidroelektrana sa manjim akumulacijama, nuklearna energija noću. Takođe se mogu primeniti da zamene rad hidroelektrana u režimima parcijalnog opterećenja, neefikasne režime "stand-by" i rotirajuće rezerve [6]. Njihovi režimi su prilagodljivi zahtevima snabdevanja, stabilnosti i drugih karakteristika mreže.

Klasična postrojenja i tehnologije koje se primenjuju više od jednog veka suočavaju se sa izazovima. Iskustvo nas uči da veliki broj klasičnih hidroelektrana ima velike probleme u radu. Sistematska i potpuna posvećenost organizovanog transfera znanja i iskustva mogu da čine temelj za dalji napredak ka suštinskoj potrebi za zadovoljenje energije.

\section{REFERENCE}

[1] -ASME Hydro Power Technical Committee, "." The ASME Guide to Hydropower Mechanical Design, in Proc. . HCI Publication.1996 pp. 374, new edition under review (Pejovic, S. co-author).

[2] -ICF Consulting, The Economic Cost of the Blackout: An Issue Paper on the Northeastern Blackout. 2003. August 14, 2003.; http://www.solarstorms.org/lCFBlackout2003.pdf.

[3] -Electricity Consumers Resource, The Economic Impacts of the August 2003 Blackout. 2003. gas\%20markets\%20IAAE\%20Procedings.pdf.

[4] H.L. Ferreira, R. Garde, G. Fulli, W. Kling and J.P. Lopes, "Characterisation of electrical energy storage technologies." Energy, br. 53, 2013, str. 288-298. doi: 10.1016/j.energy.2013.02.037

[5] A. Gajić, S. Pejovic, B. Karney and V. Stevanovic, "Pumped hydro storage reduces electricity costs and keep wind and solar unpolluted." Energija, Ekonomija, Ekologija, UDC 621.22(497.17), pp. 32-41.

[6] H.A.R. Guzman, Value of Pumped-Storage Hydro for Wind Power Integration in The British Columbia Hydroelectric System. University Of British Columbia. 2010. PhD Thesis; https://circle.ubc.ca/bitstream/handle/2429/26233/ubc_2010_fall_rivas_humberto.pdf?sequence=1.

[7] -Hatch Ltd., OPG's Deep Geologic Repository for L\&ILW - Preliminary Design Report. Nuclear Waste Management Organization ("NWMO"). Retrieved 04 06, 2011, from: http://www.nwmo.ca/uploads_managed/MediaFiles/1606_h333000-wp700-05-124-0001.pdf.

[8] G. Keil, Germany's Energy Supply Transformation Has Already Failed. European Institute for Climate and Energy. 2011. Preuzeto sa: http://www.eike-klima-energie.eu/news-cache/germanys-green-energy-supplytransformation-has-already-failed/.

[9] T. Maricic, W.B. Karney and S. Pejovic, "Knowledge Transfer with Intention to Improve Design While Reducing Operational Expenses", u VIPSI, Belgrade. 2009.

[10] J.R. Minkel, "The 2003 Northeast Blackout: Five Years Later." Scientific American, 2008 Preuzeto sa: http://www.scientificamerican.com/article.cfm?id=2003-blackout-five-years-later

[11] J.J. Muir, Analysis of UK Wind Power Generation November 2008 to December 2010. National Wind Watch. 2011. (John Muir Trust and Stuart Young Consulting), April 7.. Preuzeto sa: http://www.windwatch.org/documents/analysis-of-uk-wind-power-generation-november-2008-to-december-2010/

[12] -Ministry of Energy, Ontario's Long-Term Energy Plan: Building Our Clean Energy Future 1. IESO. 2011. Preuzeto sa: http://www.ieso.ca/imoweb/pubs/consult/sac/sac-20110302-Item5_LTEP.pdf. 
[13] L.A. Patrick, "Northeast Blackout Likely to Reduce US Earnings by \$6. 4 Billion." AEG Working Paper, br. 2, 2003 Preuzeto sa: http://www.andersoneconomicgroup.com/Portals/0/upload/Doc544.pdf

[14] S. Pejovic, A. Gajic, B. Karney and B. Bergant, "Pumped and Hydro Storage Reduce Electricity Costs", u Clean Environment and Keep Wind and Solar, Int. Conf. Thynk-Hydro.com, Resita, Romania. 2013.

[15] S. Pejovic, B.W. Karney, Q. Zhang and G. Kumar, "Smaller Hydro, Higher Risk", u 2007 IEEE Canada Electrical Power Conference, Montreal. Institute of Electrical and Electronics Engineers (IEEE). 2007, str. 91-96 doi: 10.1109/epc.2007.4520312

[16] S. Pejovic, C. Kennedy, B. Karney and T. Maricic, "Achieving a Comprehensive and Integrated Energy System through Electricity", u IPSI, Belgrade. 2009. Preuzeto sa: http://internetjournals.net/journals/tar/2008/July/Full\%20Journal.pdf

[17] S. Pejovic, Q. Zhang, B. Karney and A. Gajic, "Key invited presentation, Analysis of Pump-Turbine "S" Instability and Reverse Waterhammer Incidents in Hydropower Systems", u 4-th International Meeting on Cavitation and Dynamic Problems in Hydraulic Machinery and Systems, Belgrade, October 26-28, 2011. 2011. Links: Aarticle: IAHR WG Bgd 20114-th International Meeting onPub31381.pdf and; Presentation: IAHR WG Bgd Oct 2011 Pejovic BG KZ AG Keynote Instability Reverse WH Incidents.pdf. Preuzeto sa: http://info.ornl.gov/sites/publications/files/Pub31381.pdf

[18] M. Shwartz, Stanford scientists calculate the carbon footprint of grid-scale battery technologies, Stanford Report. 2013. Preuzeto sa: http://news.stanford.edu/news/2013/march/store-electric-grid-030513.html

[19] -David Suzuki Foundation, Smart Generation, Powering Ontario with Renewable Energy, Report. 2004. Preuzeto sa: http://www.davidsuzuki.org/publications/downloads/2004/Smart_Generation_summary.pdf.

[20] J. Spears, Ontario energy plan raises tough issues. Toronto Star. 2010. Published Nov 24 2010. Preuzeto sa: http://www.thestar.com/business/companies/article/895694--ontario-energy-plan-raises-tough-issues

[21] R. Stasko and S. Pejovic, Developing The Business Case for a Pumped Storage Project In Ontario, Ministry of Energy RFI (Request for Information), 2013, Sci (Science Concepts International. Ontario: Ministry of Energy / Sci (Science Concepts International. 2013. RFI (Request for Information).

[22] H. Tanaka, Benefits of pumped storage; Advanced Sustainable Hydropower. International Hydropower Association. 2005. Preuzeto sa: http://www.hydropower.org/psd/articles/benefits.html

[23] R.S. Walawalkar, Economics of Emerging Electric Energy Storage Technologies and Demand Response in Deregulated Electricity Markets. Carnegie Mellon University. 2008. Preuzeto sa: http://wpweb2.tepper.cmu.edu/ceic/theses/Rahul_Walawalkar_PhD_Thesis_2008.pdf.; PhD Thesis

[24] R. Walawalkar, J. Apt and R. Mancini, Carnegie Mellon Electricity Industry Center Working Paper CEIC. 0604.. Preuzeto sa: https://wpweb2.tepper.cmu.edu/ceic/pdfs/CEIC_06_04.pdf

[25] E. Williams, Dinorwig, the Electric Mountain, Public Relations. London: National Grid Company plc. National Grid Hiuse, Summer Street, London SEI 9JU, Registered in England and Wales No2366877 (year of publication not available).

[26] T. Weber, Toll from Blackout Could Reach \$2-Billion: Cfib. 2003. Be and Mail September 11, http://www.globeinvestor.com/servlet/ArticleNews/story/RTGAM/20030911/wbbiz0911.

[27] D.V. Zandt, L. Freeman, G. Zhi, R. Piwko, G. Jordan, N. Miller and M. Brower, Wind Integration Study. Ontario: Ontario Power Authority (OPA) / Independent Electricity System, Operator (IESO) / Canadian Wind Energy Association (CanWEA). Final Report, EB-2007-0707, Exhibit D-5-1, Attachment 2. Preuzeto sa: http://www.powerauthority.on.ca/sites/default/files/page/4536_D-5-1_Att_2.pdf 